\title{
РОЛЬ ВЛКСМ В ФОРМИРОВАНИИ УПРАВЛЕНЧЕСКИХ КАДРОВ
}

\author{
Т. А. Портнова \\ Московская городская Дума
}

Аннотация: В статье анализируется роль ВЛКСМ в воспитание талантливых организаторов в разных областях народного хозяйства в советское время.

Ключевые слова: ВЛКСМ; управленческие кадры; история СССР; комсомол; пятилетка; организатор; народное хозяйство

\section{ROLE OF THE ALL-UNION LENINIST YOUNG COMMUNIST LEAGUE IN THE FORMATION OF MANAGERIAL PERSONNEL}

\author{
T. A. Portnova \\ Moscow City Duma
}

Abstract: The paper analyses the role of the All-Union Leninist Young Communist League in the education of talented organisers in various spheres of the national economy during the Soviet era.

Keywords: All-Union Leninist Young Communist League; managerial personnel; history of the USSR: Komsomol; five-year plan; organiser; national economy

С первых лет Советской власти кадровая политика партии и комсомола постоянно была направлена на то, чтобы тщательно отбирать, выращивать и воспитывать талантливых организаторов из народной среды, способных умело руководить созидательным творчеством масс.

Нас учили, что комсомол - это «резерв и помощник партии». Комсомол должен «организовывать», «мобилизовывать» молодежь на нужные для страны дела. Это правильно. В этом смысле он «инструмент», «средство», «приводной ремень».

Молодежь всегда была движущей силой, воспитывалась на идеалах справедливости, добра, преданности своему делу. Комсомольские организации сыграли большую роль в жизни нашего поколения. Все без исключения знаковые объекты в Советском Союзе построены при активном участии комсомольцев, на их энтузиазме. Никого тогда не удивляло, что молодые ребята и девушки едут работать по «комсомольским путевкам» - отправ- 
ляются в тундру, тайгу, на целинные земли. Комсомол всегда был окружен ореолом романтики, боевых и трудовых подвигов на благо Родины. Подавляющее число сегодняшних высших менеджеров и во власти, и в бизнесе сформировались как руководители именно в комсомоле.

Уже в 1923 г. был поставлен вопрос об овладении молодежью наукой и техникой. А в годы восьмой пятилетки (1966-1970гг.) комсомольские организаторы располагали богатым арсеналом сложившихся и хорошо зарекомендовавших себя форм работы по развитию технического творчества юношей и девушек. Это движение рационализаторов и изобретателей, работа общественных конструкторских бюро (ОКБ), студенческих КБ, Советов молодых ученых и специалистов, шефство над внедрением новой техники и многое другое.

В 1960-е гг. предпринимались попытки освоения нолвых форм социальной и производственной активности молодежи. В 1966 г. в Новосибирске было создано молодежное научно-производственное объединение «Факел». Основная его задача заключалась в привлечении молодежи к активному участию в научной, производственной и хозяйственной жизни. НПО «Факел» - прообраз первого в России технопарка, был создан в Академгородке под Новосибирском.

Основу НПО составляли молодые инженеры и ученые, выполнявшие научные работы на подрядной основе - самодеятельной общественной организации на базе районной комсомольской ячейки.

НПО «Факел» выполнило более пятисот хоздоговоров, при этом себестоимость различных работ в объединении была в 5-20 раз ниже, чем в других научно-производственных организациях СССР.

Как бы разворачивались события, если бы самодеятельному КБ «Факел» не мешали работать, в особой помощи он не нуждался, лишь бы не мешали... Я уверена, что через несколько лет наша страна имела бы эталоны, на которые пришлось бы равняться не только отраслевой науке. Какой бы это был важный пример в поисках новых организационных форм работы, которые сейчас ведутся по всей стране. И все бы увидели, что несколько талантливых энтузиастов и настоящих профессионалов способны заменить огромные организации со многими сотнями сотрудников, или, точнее, служащих. Слов нет, эти инициативные люди и зарабатывали бы как следует, как следует их таланту, энергии, работоспособности и трудолюбию.

В истории с «Факелом», разумеется, пришлось бы переступить через некоторые инструкции финорганов, поставить вопрос об их несоответствии современным задачам развития государства. Может быть, пришлось бы по шире рассмотреть всю совокупность проблем, которые ставит возникновение подобных самодеятельных организаций. 
Научные труды Московского гуманитарного университета 2018 № 6

Боялись конкуренции? Конечно, и не без оснований! Считали конкуренцию недопустимой (лезут не в свое дело), а это не только потеря гражданственности, но и нечто большее и весьма опасное для нашего будущего. Давно уже следует усвоить простую истину: страна только выиграет, если обнаружится никчемность того или иного учреждения и необходимость его ликвидации или коренной перестройки. В то время, когда шла дискуссия о «Факеле», произносились и другие слова. В частности, они шли и от «теоретиков». Не вписывается, мол, «Факел» в стройную систему управления народным хозяйством, все это неоправданная отсебятина.

Несмотря на успехи, НПО «Факел» в начале 1968 г. закрыли, объяснив это тем, что его работа способствовала «развитию частной предпринимательской деятельности». Новые неформальные способы работы с молодежью явно не приживались, т. к. противоречили существовавшим партийно-идеологическим подходам. Комсомол также оказался не готовым к новым запросам молодежи в социально-бытовой и культурно-досуговой сфере, возникнолвению неформальных организаций. Из руководства ВЛКСМ вышли предприимчивые молодые люди, составившие впоследствии бизнес-элиту современной России.

Но именно из комсомола вышли первые в СССР легальные предприниматели, что и определило лицо постсоветской бизнес-элиты России. В далеком 1971 г. молодежи Подмосковного города Калининград (ныне Королев), для которой катастрофически не хватало жилья, предложили самим строить для себя дома по системе хозрасчета. Так, при непосредственном контроле и участии местных комсомольских организаций возникли молодежные строительные кооперативы (МЖК). Потом на их основе были созданы строительные компании. В МЖК комсомольцы прошли неплохую школу бизнеса: в условиях хозрасчета им приходилось самостоятельно планировать бюджет организации, торговаться за дефицитные стройматериалы, вести переговоры с подрядчиками.

Другой формой комсомольского предпринимательства были центры научно-технического творчества молодежи (НTTM), созданные по постановлению Совета министров СССР в 1987 г. Названию своему они не соответствовали - большей частью их участники закупали сырье по государственной цене и перепродавали его с наценкой кооперативам, производившим ширпотреб. Особенно прибыльной была торговля закупленными за рубежом подержанными компьютерами в рамках горбачевской программы информатизации страны. Кстати, печально известная компания «МММ» выросла именно из НТТМ и в первые годы после развала СССР занималась продажей компьютеров и периферии. А $20 \%$ московского бизнеса того времени было так или иначе связано с ВЛКСМ. «Менатеп», Кредобанк (первый 
советский банк, выпустивший кредитную карту) основали именно комсомольские активисты.

Комсомол - «страна молодежи»! Каждый вправе был сам определять цену своей личности и своей роли в жизни комсомола - молодежной организации, которая сегодня не существует, но дела которой и имена людей, их сотворивших, вычеркнуть из истории Отечества невозможно.

Комсомол - организация феноменальная, уникальная по динамичности, мобильности и управляемости. Весьма «жесткая» по принципам строения и деятельности, она тем не менее объединяла десятки миллионов молодых людей. В 1980-х годах в комсомоле, например, состояло более 40 млн юношей и девушек. Благодаря комсомолу не было «потерянных» поколений.

Энтузиазмом и энергией молодежи - комсомольцев прежде всего Россия в 1930-х была превращена в могучую индустриальную державу. А победа в Великой Отечественной войне? Ведь солдаты, сотни тысяч которых легли на ее полях, - это были люди прежде всего молодые, комсомольцы. А восстановленное за пять послевоенных лет разрушенное народное хозяйство? А поднятая целина?

Комсомол был одним из несущих звеньев жесткой конструкции политической системы советского общества, играл огромную роль в экономических и социальных преобразованиях. Во всех выдающихся и великих переменах и достижениях, произошедших в жизни народов СССР, есть весомый вклад комсомола.

Дата поступления: 20.08.2018 2.

Портнова Татьяна Арториджевна - кандидат политических наук; депутат Московской городской Думы, Председатель комиссии Думы по государственному строительству и местному самоуправлению, член объединенной комиссии Московской городской Думы и Московской областной Думы по координации законотворческой деятельности. Адрес: 127994, Россия, г. Москва, ГСП-4, Страстной бульвар, д. 15/29, стр. 1. Эл. адрес: spravka@ duma.mos.ru

Portnova Tatyana Artoridzhevna, Candidate of Political Science, Deputy, Moscow City Duma; Chairperson of the Duma Committee for State Construction and Local Governance; Member of the United Committee Of Moscow City Duma and Moscow Region Duma for Coordination of Legislation. Postal address: 15/29, Bldg. 1, Strastnoy Blvd., Moscow, GSP-4, Russian Federation, 127994. E-mail: spravka@duma.mos.ru 


\section{Для цитирования:}

Портнова Т. А. Роль ВЛКСМ в формировании управленческих кадров [Электронный ресурс] // Научные труды Московского гуманитарного университета. 2018. № 6. URL: http://journals.mosgu.ru/trudy/article/view/833(дата обращения: дд.мм.гг.). DOI: 10.17805/trudy.2018.6.2 